\title{
A Study on Comparison of Index Returns and Returns of Portfolio Created Using Equal Weight Age Index Method
}

\section{A. Arun Prakash}

Happy Valley Business School Coimbatore.

\begin{abstract}
*Corresponding Author Email: arunprakash.hvbs@gmail.com
Abstract: The main aim of the study is to select a list of companies from the basic indices of NSE like Nifty50, Next50 and Small Cap 50, to create a portfolio of the companies with respect to the indices selected for the study which results in 3 different portfolios. Portfolio 1 represents 29 scrips selected from Nifty50, Portfolio 2 represents 30 scrips selected from the Next50 index, and Portfolio 3 represents 34 scrips selected from Small Cap index. After creating the portfolios, Each scrip under each portfolio will be invested with Rs.1,00,000, each scrip in each portfolio will be given equal weightage so the total investment will be Rs.29,00,000, Rs.30,00,000 and Rs.34,00,000, under Portfolio 1,2 and 3 respectively. To prove the factor that the returns of the created portfolio has beaten the index returns the price data of all the scrips for the past 10 years were taken and the returns were computed for the portfolio year on year and from 2008 to 2018.
\end{abstract}

Keywords: Index Returns, Returns of Portfolio, Equal Weight Age Index Method

\section{Introduction}

Every individual would have one objective in common that would be creation of montem of wealth and prosper in life. Building riches through the active income (salaried, business, or professional) is merely impossible, so it is important to create a passive income and that is making money to work for us rather we working for it, the best way to do so is parking money in best investment vehicle.

The billionaires and value investors like Buffett, Graham, Hill, Jhunjhunwala, Damani showed the way to Capital Market (Stock Market) that people can travel to the destiny of creating riches. Individuals start believing that the best way to create a passive income is investing in stocks of the company. But every individual as investor has different techniques to invest and make money and none of the techniques can be claimed as never-failing technique. Market is purely inefficient that could be the only source to make money, investors grow more interest in knowing the various techniques to reach the objective either in mid or long term of investment. Most of the traditional investors have the attitude of selecting a company; invest in by buying the stocks of the company sit tight for long term. But there is a risk of losing the money, to prevent it is always better to create portfolio of companies and invest in that portfolio. Following the traits of Greenblatt and Graham, we derive yet another technique to invest in portfolio of stocks.

\section{Selection of Stocks}

The companies are selected from the basic Nifty50 Index, Next 50 Index \& Small Cap Index, and the basic determinant to select the stock is, the companies should have zero debt and minimum of $20 \%$ ROA for the past 10 years and a highest earnings yield, and the companies should have good basic 
fundamentals in regard to efficiency, profitability and liquidity of the companies.
After cross checking the companies we arrived at the top list for each index which is been tabled in Table No.

Table1: Table showing the selected companies for the various portfolios

\begin{tabular}{|c|c|c|c|}
\hline \multirow{2}{*}{$\begin{array}{c}\text { Serial } \\
\text { Numer }\end{array}$} & Portfolio 1 (p1) & Portfolio 2 (p2) & Portfolio 3 (p3) \\
\hline & Nifty50 index & Nifty next50 index & Nifty small 50 index \\
\hline 1 & Adani ports & Acc cements ltd & $8 \mathrm{k}$ miles ltd \\
\hline 2 & Asian paints & Ambuja cements ltd & Apollo tyres \\
\hline 3 & Bajaj finserves & Ashok leyland & Ashok leyland \\
\hline 4 & Eicher motors & Aurobindo pharma & Atul auto \\
\hline 5 & Grasim ind & Bel & Beml \\
\hline 6 & $\mathrm{Hcl}$ & Bosch ltd & Bluestar \\
\hline 7 & Hdfc & Britannia & Bse \\
\hline 8 & Hdfc bank & Colgate palmolive & Capfis \\
\hline 9 & Hero moto corp & Concor & Cochin shipyard \\
\hline 10 & Hindalco ltd & Cummins ind & Exide ind \\
\hline 11 & $\mathrm{Hul}$ & Dabur india & Federal bank \\
\hline 12 & Indusind bank & Dlf & Gati \\
\hline 13 & Infosys & Emami & Hexaware \\
\hline 14 & Ioc & Godrej & Ht media \\
\hline 15 & Itc & Havells & Indian terrain \\
\hline 16 & Kotak bank & Hinzinc & Jamna auto \\
\hline 17 & L\&t & Jsw steel & Karur vysya bank \\
\hline 18 & Lupin & L\&t fin & Marico \\
\hline 19 & $\mathrm{M} \& \mathrm{~m}$ & Lic housing finance & Mastek \\
\hline 20 & Maruti & Marico & Mindtree \\
\hline 21 & Powergrid & Motherson sumi & Mmtc \\
\hline 22 & Reliance ind & Mrf & Moil \\
\hline 23 & Tatasteel & P\&g & Nilkamal \\
\hline 24 & Tes & Pidilite ind & Quess \\
\hline 25 & Techm & Power finance & Radico ind \\
\hline 26 & Titan ind & Sail & Rain ind \\
\hline 27 & Wipro & Shree cements & Sonata \\
\hline 28 & Yes bank & Siemens & Tata met \\
\hline 29 & Zee entertainment & Sree transport \& fin & Tatasponge \\
\hline 30 & & Suntv network & Ttk prestige \\
\hline 31 & & & Tvs motors \\
\hline 32 & & & $\mathrm{~V}$ guard \\
\hline 33 & & & Vakarangee \\
\hline 34 & & & Vip ind \\
\hline & Total no. of scrips $=29$ & Total no. of scrips $=30$ & Total no. of Scrips $=34$ \\
\hline
\end{tabular}

Table 2: Table Showing Comparison of Real Returns of Selected 29 Scrips form Nifty 50 Index with Real Returns of Nifty 50 Index

\begin{tabular}{|c|c|c|c|c|}
\hline \multicolumn{5}{|c|}{ Selected 29 Scrips form Nifty 50 Index } \\
\hline $\begin{array}{c}\text { Investment } \\
\text { Tenure }\end{array}$ & $\begin{array}{c}\text { \% Growth of } \\
\text { Portfolio } \\
\text { Returns }\end{array}$ & $\begin{array}{c}\text { \% Growth of } \\
\text { Index } \\
\text { Returns }\end{array}$ & $\begin{array}{c}\text { Real Growth of } \\
\text { Initial Investment } \\
\text { Rs.29,00,000 } \\
\text { (Values in Rs.) }\end{array}$ & $\begin{array}{c}\text { Real Growth of } \\
\text { Initial Investment } \\
\text { in Nifty 50 Index } \\
\text { Rs.29,00,000 } \\
\text { (Values in Rs.) }\end{array}$ \\
\hline $2008-2018$ & 1316 & 163 & $4,10,55,535$ & $76,27,000$ \\
\hline $2009-2018$ & 1130 & 147 & $3,56,74,410$ & $71,63,000$ \\
\hline $2010-2018$ & 465 & 100 & $1,63,71,042$ & $58,00,000$ \\
\hline $2011-2018$ & 360 & 88 & $1,33,55,866$ & $54,52,000$ \\
\hline $2012-2018$ & 289 & 101 & $1,12,70,506$ & $58,29,000$ \\
\hline $2013-2018$ & 203 & 82 & $87,78,919$ & $52,78,000$ \\
\hline $2014-2018$ & 107 & 40 & $60,16,598$ & $40,60,000$ \\
\hline $2015-2018$ & 59 & 27 & $46,20,702$ & $36,83,000$ \\
\hline $2016-2018$ & 44 & 28 & $41,68,141$ & $37,12,000$ \\
\hline $2017-2018$ & 14 & 12 & $33,02,445$ & $32,48,000$ \\
\hline
\end{tabular}


The above table shows the comparison of real growth of investment in portfolio 1 with the growth of investment in Nifty 50 index. When considering the investment tenure of 2008-2018 for the total investment of Rs.29, 00,000 the total return in percentage id around Rs.4 Crores, which means the money, has got more than double on every consecutive year which is unbelievable, none of the investment alternative could have fetched such huge returns. On comparing with Nifty 50 index returns, for the same total investment of Rs.29, 00,000 across all index scrips and for the same 2008-2018 investment tenure the growth of the returns is only $163 \%$, where the Rs.29,00,000 would have grown up to Rs. 76,27,000.

More importantly, the returns are more constant and the portfolio returns is beating the market returns for all investment tenures. The basic understanding from the table is the returns are more surgical when you begin your investment early [1-4].

Table 3: Table Showing Comparison of Returns Selected 29 Scrips form Nifty Next50 Index with real returns

\begin{tabular}{|c|c|c|c|c|}
\hline \multicolumn{5}{|c|}{$\begin{array}{c}\text { Selected 30 Scrips form } \\
\text { Next 50 Index }\end{array}$} \\
\hline $\begin{array}{c}\text { Investment } \\
\text { Tenure }\end{array}$ & $\begin{array}{c}\text { \% Growth } \\
\text { of Portfolio } \\
\text { Returns }\end{array}$ & $\begin{array}{c}\text { \% Growth } \\
\text { of Index } \\
\text { Returns }\end{array}$ & $\begin{array}{c}\text { Real Growth of Initial } \\
\text { Investment } \\
\text { Rs.30,00,000 (Values } \\
\text { in Rs.) }\end{array}$ & $\begin{array}{c}\text { Real Growth of Initial } \\
\text { Investment in Next 50 } \\
\text { Index Rs.30,00,000 } \\
\text { (Values in Rs.) }\end{array}$ \\
\hline $2008-2018$ & 861 & 248 & $2,88,21,354$ & $1,04,30,572$ \\
\hline $2009-2018$ & 717 & 301 & $2,45,24,029$ & $1,20,24,010$ \\
\hline $2010-2018$ & 798 & 172 & $2,69,39,249$ & $81,50,281$ \\
\hline $2011-2018$ & 320 & 152 & $1,26,10,251$ & $75,72,957$ \\
\hline $2012-2018$ & 295 & 202 & $1,18,54,291$ & $90,71,504$ \\
\hline $2013-2018$ & 218 & 132 & $95,54,029$ & $69,55,409$ \\
\hline $2014-2018$ & 108 & 72 & $62,28,603$ & $51,58,735$ \\
\hline $2015-2018$ & 57 & 44 & $46,95,767$ & $43,08,679$ \\
\hline $2016-2018$ & 39 & 45 & $41,78,740$ & $43,43,427$ \\
\hline $2017-2018$ & 11 & 9 & $33,21,156$ & $32,61,789$ \\
\hline
\end{tabular}

Table 4: Table Showing Comparison of Returns Selected Scrips form Nifty Under50 Index with real returns

\begin{tabular}{|c|c|c|c|c|c|}
\hline \multicolumn{7}{|c|}{$\begin{array}{c}\text { Selected 34 Scrips form } \\
\text { Under 50 Index }\end{array}$} \\
\hline $\begin{array}{c}\text { Investment } \\
\text { Tenure }\end{array}$ & $\begin{array}{c}\text { \% } \\
\text { Growth } \\
\text { of } \\
\text { Portfolio } \\
\text { Returns }\end{array}$ & $\begin{array}{c}\text { \% } \\
\text { Growth } \\
\text { of Index } \\
\text { Returns }\end{array}$ & $\begin{array}{c}\text { Real Growth } \\
\text { of Initial } \\
\text { Investment } \\
\text { (Values in Rs.) }\end{array}$ & $\begin{array}{c}\text { Real Growth of } \\
\text { Initial } \\
\text { Investment in } \\
\text { Next 50 Index } \\
\text { Rs.30,00,000 } \\
\text { (Values in Rs.) }\end{array}$ & $\begin{array}{c}\text { Changing } \\
\text { Initial } \\
\text { Investment }\end{array}$ \\
\hline $2008-2018$ & 1256 & 101 & $3,39,01,345$ & $50,28,727$ & $25,00,000$ \\
\hline $2009-2018$ & 1232 & 162 & $3,32,89,191$ & $65,48,358$ & $25,00,000$ \\
\hline $2010-2018$ & 509 & 92 & $1,58,35,276$ & $49,82,697$ & $26,00,000$ \\
\hline $2011-2018$ & 411 & 92 & $1,48,12,851$ & $55,71,012$ & $29,00,000$ \\
\hline $2012-2018$ & 481 & 114 & $1,68,61,526$ & $62,12,925$ & $29,00,000$ \\
\hline $2013-2018$ & 544 & 147 & $1,93,16,273$ & $74,09,153$ & $30,00,000$ \\
\hline $2014-2018$ & 243 & 33 & $1,06,30,335$ & $41,28,540$ & $31,00,000$ \\
\hline $2015-2018$ & 147 & 35 & $76,65,594$ & $41,79,729$ & $31,00,000$ \\
\hline $2016-2018$ & 99 & 23 & $61,83,676$ & $38,27,404$ & $31,00,000$ \\
\hline $2017-2018$ & 35 & -2 & $44,63,758$ & $32,39,516$ & $33,00,000$ \\
\hline
\end{tabular}




\section{Conclusion}

On comparing the index returns with the portfolio returns the returns from the portfolio has outnumbered the index returns, so the screening of the stocks using Greenblatts ratios (ROA, ROCE, EY) the portfolio constructed using the stocks will have a top performance.

\section{Reference}

1 www.screener.in

2 www.moneycontrol.com

3 www.yahoofinance.com

4 "The Little Book that Beats the Market" by Joel Greenblatt "Value Investing" by Benjamin Graham 